DOI https://doi.org/10.36059/978-966-397-235-0-7

\author{
Ennan R. Ye., \\ Candidate of Legal Sciences (PhD in Law), \\ Associate Professor at the Department of Intellectual Property Law \\ National University "Odesa Law Academy", \\ Odesa \\ Menso I. V., \\ Candidate of Legal Sciences (PhD in Law), \\ Senior Lecturer at Civil and Labor Law Department \\ Odesa National Maritime University, \\ Odesa
}

\title{
INTELLECTUAL PROPERTY IN THE HUMAN RIGHTS SYSTEM: GENERAL PRINCIPLES
}

Summary. The institute of intellectual property law had a rather long period of development. It has become widespread in the modern world and is enshrined in both domestic and international law. International human rights law enshrines as fundamental rights the freedom of creativity, the right to protect the moral and material interests of authors. This formed the basis for the further enshrinement of intellectual property rights in the constitutions of the world.

The importance of intellectual property is indicated by the fact that the constitutions of many modern states have not ignored this important area of human relations. Public recognition of intellectual property and its protection in constitutions have become an act of the greatest constitutional, scientific and practical significance.

The development of intellectual activity and intellectual property will be largely determined by the attitude of the state and society to the person of the creator, which should be defined in the constitutions. This is especially true in the information society, when one of the main social values is the creative activity of man.

The main modern international legal documents on human rights are analyzed, in which the provisions on intellectual property are revealed. The new international legal documents contain important provisions for understanding the essence and features of the realization of the human right to the results of creative activity and protection of intellectual property in the conditions of information and communication technologies and knowledge economy. 


\section{Introduction}

Today, intellectual potential has an extremely important role in the life of society and the state. It is no coincidence that new conceptions of the essence of the modern state have emerged, which connect its future with the role of people of mental labor. This is due to the progressive trend of scientific and technological progress, the need for humanization, changes in the structure, quality and number of major productive forces in society. It is today that the urgent question of the need for effective protection and defense of intellectual property arises. In the third millennium, the achievements of the individual will increasingly contribute to the growth of firms, teams, countries.

The development of these principles requires the recognition of such axioms as respect for the individual, partnership, mutual responsibility. First of all, when it comes to the protection of intellectual property, it is necessary to talk about the protection of the rights of the creator.

The Universal Declaration of Human Rights of 1948 proclaimed the right to freedom of opinion and expression, as well as the right to information - the freedom to seek, receive and impart information and ideas by any means and regardless of state borders. Article 27 of the Universal Declaration of Human Rights of 1948 states that everyone has the right to the protection of the moral and material interests resulting from scientific, literary and artistic values.

Today, in our opinion, it should be a question of ensuring the security of intellectual property and its creators. The legal protection of the intellect must be based on the need for consistent observance of the guarantees of inalienable human rights. This principle is enshrined in the International Covenant on Economic, Social and Cultural Rights.

Thus, in particular, it proclaims the human right to use the protection of moral and material interests arising in connection with any scientific, material or artistic works, the author of which he is, necessary for scientific research and creative activities, on the conditions and guarantees of initiative in all spheres of economic, social, political and cultural life, regarding the realization of its political and civil rights.

Significant intellectual potential will be effective only if an effective system of protection of the interests of authors and right holders is created, which will really work and be guaranteed by the state. 
However, today the imperfection of the legal levers of protection and development of intellectual property is evident. So, first of all, it is necessary to deal seriously with the problems of protection and defense of intellectual property at the national level.

In our opinion, in order to build a quality and effective system of protection and defense of creative personality and the results of its work, it is necessary to proceed from the basic constitutional norms that determine the legal status of the individual in the field of spiritual and cultural relations. Thus, there is obviously a problem with the place and role of constitutional law in regulating intellectual property issues.

\section{The human right to the results of intellectual and creative activity and intellectual property}

Intellectual property is traditionally considered as an object of legal sciences. It functions in different legal regimes as a system embodied in regulations that define the rights of authors, inventors, scientists, cultural figures. M. Keizerov was one of the first to develop the issue of philosophical approaches to intellectual property, who in his article "Spiritual property as a complex problem" offered his vision of the philosophical content of this category: "In the foreground in intellectual property can highlight the opinion and view, her knowledge, experience. This array of accumulated culture and its monuments, achievements of science, universal values and heritage of civilization as a whole, each nation, social group, are open to all. However, along with the global philosophical approach is quite legitimate and one in which intellectual property appears in a particular type of inventions and innovations, discoveries, works of literature and art, science, in short, the objects of creative work, objectified, given directly in the form the results of mental work or intertwined with other activities mediated by them" [1].

In her monograph "Intellectual Property and Intellectual Owners" A. Orekhova [2] proposed an original theory of "overstrata" intellectual owners, ie individuals in whom the main type of ownership is the ownership of knowledge and information. They earn a living using their knowledge and skills, they are paid primarily for the knowledge they have accumulated over a lifetime and for the return that society receives from the fact that this knowledge works. Empirically, the "overstrat" of intellectuals includes representatives of various professions: teachers, scientists, writers, artists, etc. Their 
properly protected rights are a guideline for the development of intellectual property rights in the information age. At the center of the social transformations that accompany the construction of the information society is the person, his needs and interests.

The Okinawan Charter of the Global Information Society emphasizes that the essence of the transformation brought about by information and communication progress is its ability to assist people and society in the use of knowledge and ideas. The European Union has issued a Green Paper "Living and working in an information society: people first" [3].

One of the challenges facing society in technological progress is the training of human resources, people who are educated and able to use information technology. In another document - the EU Action Plan "Information Society for All" among the measures to build an information society, along with such as free access to the Internet, personal data protection, prevention of stratification of society into "information rich" and "information poor", and others, separate protection of information intellectual property [4]. The human dimension of the essence of the information society is clearly stated in the Tunisian Commitment of the World Summit on the Information Society on 18 November 2005: "We reaffirm our commitment and determination to build a people-centered, open to all and developing the information society on the basis of the aims and principles of the UN Charter, international law and the principles of multilateral agreements, fully respecting and upholding the Universal Declaration of Human Rights, so that people around the world can create, access, enjoy and enjoy information and knowledge. to exchange them in order to reach their full potential" [5].

In the information society, one of the main social values is the creative activity of man, because the main resource is intellectual potential. The new knowledge-based economy gives birth to a new social group of people, which in Western sociology is called knowledgclass, and E. Toffler 159 defines it as a "cognitar" and predicts its future role as a structural determinant of social governance in all spheres of society. life. Professionalism and the ability to be creative, a person's desire for self-improvement become the criteria that determine his social status.

Sociologist S. Lesch in his work "Critique of Information" [6] notes the specifics of the information society and shows that it gives birth to new patterns of production, distribution and exchange, in which 
information that formally knows no boundaries, is organized by the intellectual property system. Intellectual property acts as a strategic resource of modern innovative development, which is based on the creative activity of the individual. Man and his creative potential, scientists as subjects of socially transforming innovations determine the main vectors of development of the world and national communities.

M. Castells, the creator of the theory of information network society, notes that intellectual property is a mechanism of selfaffirmation of new social groups - managerial and intellectual elites who have the right to own knowledge and information [7]. Already in Hegel's "Philosophy of Law" it was about the special importance of protecting scientists and artists from arbitrariness and encroachment on their rights, the protection of the state by their spiritual property as a task to encourage creativity "just as the first important incentives for industry was to protect it from robbery on the highway" [8].

Hegel highlighted the peculiarity of "products of spiritual labor" and the specifics of ownership, noted the special nature of copyright and invention rights with the separation of property rights and rights of use, reproduction, general reception and method of production, skills on the border art. The American sociologist E. Gouldner in his work The Future of Intellectuals and the Rise of the New Class [9] made the first serious attempt to link the problem of intellectual property and the problem of intellectuals, whom he considers the owners of cultural capital. Later, this idea in one form or another was developed by other Western researchers, including P. Bourdieu and E. Toffler [10].

The Universal Declaration on Intellectual Property presents the human dimension of intellectual property as fully as possible, as it focuses not so much on protecting intellectual property rights as on revealing the importance of authors and their activities in the development of culture, economy, science, art and humanity as a whole. The Declaration explains the enormous role played by intellectual property (works of art, inventions, utility models, etc.) in the industrial, scientific, cultural, and spiritual development of human society. The main thing in this international legal document is [11]. Intellectual property rights stimulate authors and provide users with equal access to the benefits of creative activity. Intellectual property rights are an important and integral part of any legal framework that aims to regulate on a fair basis the civil conduct of authors and users and thus ensure the universal protection of the interests of all. Intellectual property rights are a key and integral tool in the effort to 
address the fundamental challenge of development for all, which at the end of the twentieth century is the most important and universally recognized problem facing humanity. The great contribution made by the authors to the history of mankind both in the past and today, as well as the achievements of those who disseminate information about the benefits of these creations and inventions, have received recognition, appreciation and support. Intellectual property rights need to be further developed to ensure the right balance between copyright protection and user interests.

This document recommends actions to be taken by governments in relation to intellectual property creators living and working in their countries: all those who create or want to create should be encouraged; Efforts should be intensified to ensure that all authors and users in any part of the world receive the appropriate intellectual property rights; full support should be given to the efforts of developing countries and countries with economies in transition to unleash and realize for their own benefit their inventive and creative potential, to create and improve effective national intellectual property systems; adequate resources must be allocated for these purposes in order to ensure that all countries have an equal opportunity to benefit from the results of a knowledge-based society; taking full advantage of information technology, steps should be taken to ensure that authors and users around the world are aware of their rights through ongoing efforts to raise public awareness of intellectual property rights and to demystify intellectual property issues; making full use of information technology, efforts should be made to disseminate and expand public knowledge about intellectual property and intellectual property rights in order to increase interest in intellectual creativity; taking full advantage of information technology, measures should be taken to depoliticize intellectual property issues through ongoing efforts to raise public awareness of the common benefits associated with intellectual property and intellectual property rights; the great influence on the intellectual property rights of the integration of the economies of different countries and the rapid development of information technologies should be recognized and taken into account. In general, this document also outlines issues of international cooperation in the field of identification and protection of authors, intellectual property and rights to it, as well as encouragement and encouragement of authors: "Coordination of 
national policies on the establishment of intellectual property rights should be sought" [11].

In terms of innovative development, support and protection of creativity, protection of the results of creative activity become one of the main tasks of the state, which plays a leading role in the transition to the information society. This activity is directly related to the state's protection of individual freedom and human rights, without the realization of which it is impossible to develop human creativity and involve it in world cultural values and scientific achievements. Within the paradigm of the information society with its new social values and priorities there are a number of legal problems, including the problem of legal support of creative activity of the person [12].

Recognition of intellectual property rights is important in determining a person's legal status and requires legal certainty on a number of issues. From the point of view of human rights, the problem of the ratio of personal (individual) and collective (public) in intellectual property in the conditions of cooperation, collective forms of creativity needs theoretical development. In this case, the question of legal personality arises.

The subject of intellectual property in modern conditions is not only the creator, a representative of the intelligentsia, but also the right holder who bought the patent, providers - organizations that provide services on the Internet, certain segments of the population, social groups, the people as a whole. Of particular importance is the problem of conflict of public and subjective interests in the exercise of intellectual and legal relations of their rights. There are a number of questions about the extent and admissibility of legal restrictions, the need for special legal concessions of right holders and the state, which protects the interests of society as a whole. The development of information technology in the 1980s and, especially, in the 1990s determined not only the economic potential of modern states, but also determined the socio-political processes that directly affect human rights. The challenge is to update the human rights catalog. This task has been addressed by the international community at both the global and regional levels.

Global examples include the adoption by the UN General Assembly of the resolution of September 8, 2000, the Millennium Declaration [13], reaffirming the will of the world community to further develop and improve the institution of human rights in the new social realities, or UNESCO's international conferences on ethical issues society [13], 
the leading problem of which is the observance of existing human rights and the identification of new rights due to technological change. The development of new regulations in the field of intellectual property should be carried out primarily taking into account the new factors of social development due to the emergence of the Internet as a technology that best embodies the transition of mankind to the information society. In this regard, the interesting soft law document created as a result of the Intergovernmental Council for the Implementation of the UNESCO Information for All Program (IFAP) is noteworthy. The program was adopted at the 31st session of the General Conference of UNESCO in 2001.

The concept of the program is a vision of a world in which everyone has access to information important to him, and has the opportunity and skills to use the information to solve vital problems and building a better society [14]. The Program is planned and implemented under the auspices of the Interstate Council, which includes 26 UNESCO Member States elected by the UNESCO General Conference. The purpose of the Information for All Program is to: promote international consideration and discussion of ethical, legal and social issues arising from the information society [15].

In 2011, the Ad Hoc Working Group of the Information for All Program prepared a Code of Ethics for the Information Society, which was presented to the 36th session of the UNESCO General Conference [16]. The Code of Ethics is a direct result of the intergovernmental body and includes a number of regional meetings and conferences UNESCO on information ethics. The articles set out a number of universal values and guidelines, which are further proposed for use by governments in lawmaking and law enforcement. Ethical norms of the information society are established on the basis of the Universal Declaration of Human Rights and include the right to freedom of expression, the right to public access to information, in particular public information, the right to education and the right to participate in cultural life. One of the most difficult ethical issues is the problem of inequality of access to information and communication technologies (ICT) between different countries and between urban and rural communities within the country. Of particular interest is the problem of intellectual property in the information society, disclosed in paragraph 17 of document [17].

It contains a kind of program of action and methodological guidelines for determining the special role of intellectual property in a 
qualitatively new stage of human development. Intellectual property for works in the digital environment should be subject to regulation and protection by intellectual property law. Unauthorized copying and distribution of copyrighted material should not be allowed. A legal framework should be maintained that allows intellectual property owners to share and disseminate their knowledge in order to encourage open access to knowledge and promote creative activity. The application of international conventions in the field of intellectual property should be based on a fair balance between the interests of right holders and the public. At the regional level, the formation of an updated catalog of human rights in the information society is indicated in the latest Council of Europe documents. The Council of Europe is the first European international organization established in 1949 to proclaim the protection of human rights. To this end, the European Convention for the Protection of Human Rights and Fundamental Freedoms [18] was adopted and a mechanism for its implementation was provided.

The impact of information and communication technologies on human rights and the values of democracy was first considered at a 1997 conference of the Council of Ministers of the Council of Europe in Greece. The Committee of Experts of the Council of Europe on the Information Society, established by its decision, developed a document adopted in 2005 entitled "Declaration of the Committee of Ministers on Human Rights and the Rule of Law in the Information Society" [19]. The main idea of the Declaration is that such values how human rights, democracy, the rule of law, public consent and trust between people are preserved through the use of information and communication technologies (ICT). Structurally, the Declaration consists of a Preamble and two sections. The Preamble emphasizes that all the rights enshrined in the European Convention for the Protection of Human Rights and Fundamental Freedoms remain fully valid in the information age and must be protected in the future, regardless of new technological developments. At the same time, information technology can offer new opportunities for the realization of human rights, and the lack or restriction of access to ICT can deprive people of the opportunity to exercise their civil rights. The first section "Human Rights in the Information Society" contains 8 items (Right to Freedom of Expression, Information and Communication. Right to Respect for Privacy and Correspondence. Right to Education and Access to Information Technology. Prohibition 
of Slavery, Forced Labor and Trafficking in Human Beings. The right to an impartial trial and the prohibition of extrajudicial prosecution. Protection of property. The right to free elections. Freedom of assembly).

In essence, the rights and freedoms listed in the Declaration completely or partially repeat the list given in many other similar documents, in particular, in the International Bill of Human Rights. However, there are differences. For the first time, issues of public and private censorship, protection of personal information, training of people to assist in assessing the quality of information were raised. In addition, the document deals with ethics in the media sphere and the use of information technology for the development of democracy and freedom of assembly in cyberspace. Part 6 of the Declaration of the Committee of Ministers "Protection of Property" draws special attention. It emphasizes that in the field of ICT, property protection issues arise primarily in relation to intellectual property, such as patents, trademarks and copyrights. The Council of Europe's appeal to the protection of intellectual property in connection with the development of the information society is not accidental. With the change in the function of knowledge in the civilization of the XXI century, the value of intellectual property, which is inseparable from the information revolution, has sharply increased. It regulates the processes of creative, cultural and economic practice, protects the rights to objects of creative activity, becomes the main subject of management and acquires the character of an institutional phenomenon, the structures of which are leading in the information society, as in the past, ownership structures.

The Declaration of the Committee of Ministers of the Council of Europe emphasizes the dialectic of the relationship between intellectual property and ICT. The latter, on the one hand, provide new opportunities for access to intellectual property rights, and, on the other hand, can contribute to the infringement of intellectual property rights and prevent the prosecution of offenders. Meanwhile, the lack of effective measures to protect intellectual property hinders innovation and creativity, reduces investment. The document formulates an important methodological provision on state policy on intellectual property. Such a policy should pursue two objectives: first, to ensure the protection of intellectual property in accordance with the provisions of international agreements, and second, while maintaining free access to information that is in the public domain 
Права людини в Україні та у зарубіжних країнах: традиції та новації

and rejecting attempts to restrict such access and use such information [19].

The member states of the Council of Europe must endeavor to make political, social, economic and research information in the public domain, thereby expanding universal access to vital information. At the same time, the Declaration emphasizes the need to support the provisions of Art. 10 ("Infringements related to copyright and related rights") of the Council of Europe Convention on Cybercrime 179, which recommends criminal prosecution for copyright and related rights on the Internet. Thus, at the level of the Council of Europe, the possibility of applying criminal proceedings and penalties in cases of intentional infringement of intellectual property rights on a commercial scale, provided for in section 5 of Art. 61 Agreements on Trade-Related Aspects of Intellectual Property Rights (TRIPS Agreement), signed within the framework of the World Trade Organization in 1994. The second section of the Declaration of the Committee of Ministers shows a new mechanism for ensuring human rights and freedoms. It emphasizes that "building a global Information Society based on respect for human rights and the rule of law requires new forms of solidarity, cooperation and interaction between governments, civil society, the private sector and international organizations". Thus, together with states and international organizations, public organizations and private business structures are included in the human rights protection system.

The task of the member states of the Council of Europe, the Declaration emphasizes, is not only to ensure access to new technologies, but also to take measures to protect citizens from new types of human rights violations using ICT. Civil society institutions through the Conference of International Non-Governmental Organizations should be involved in the preparation of common measures for the effective promotion of human rights. Private business is encouraged to develop self-regulatory measures to ensure the right to privacy, secrecy of correspondence, and support for freedom of expression and communication. The Council of Europe, in turn, will raise awareness of the Convention on Cybercrime and its Additional Protocol, as well as the Convention for the Protection of Individuals with regard to Automatic Processing of Personal Data (ETS № 108) [20] and encourage the accession of new countries.

The Council of Europe Convention on Cybercrime was signed on 23.11.2001, ratified on 07.09.2005, and entered into force on 
01.07.2006. It contains a set of basic principles for any country that develops national computer legislation, as well as outlines the framework international cooperation. Reforms to combat cybercrime, based on the guiding principles of the Convention, are under way in Argentina, Brazil, Egypt, India, Nigeria and the Philippines. The Convention provides a clear definition of cybercrime and requires countries to establish criminal liability for four types of offenses, among which a separate group includes crimes against copyright and related rights, ie intellectual property rights. Article 10 of the Convention states that each party shall take such legislative and other measures as may be necessary to establish criminal liability under its domestic law for infringement of copyright and related rights. In this case, the necessary conditions for the onset of criminal liability are cases where illegal acts are committed knowingly, on a commercial scale and with the help of computer systems. In fulfilling its terms, the Parties to the Convention must at the same time comply with their obligations under other international instruments, including: the Paris Act of 24 July 1971 on the Berne Convention for the Protection of Literary and Artistic Works; Agreement on Trade-Related Aspects of Intellectual Property Rights; WIPO Copyright Treaty; International Convention for the Protection of Performers, Producers of Phonograms and Broadcasting Organizations (Rome Convention); WIPO Performance and Phonograms Treaty [20].

The Cybercrime Convention states that criminal liability should not apply to the violation of any moral rights of authors under these international agreements. In addition, each Party may reserve the right not to prosecute in limited cases, provided that other effective means of influence exist and that such reservation does not violate the Party's international obligations under the international instruments referred to. The Convention on Cybercrime is based on the principles of the European Convention for the Protection of Human Rights and Fundamental Freedoms. It provides conditions and guarantees for the provision of human rights in cases of criminal prosecution, as well as the preservation of the rights to freedom of expression and the right to privacy. Provisions on combating criminal infringements of intellectual property rights in cyberspace are of great methodological importance.

The Declaration of the Committee of Ministers of the Council of Europe is the first international declaration to ensure respect for human rights in the age of the Internet and modern information technology. It is the first attempt to define the legal framework in this 
area and prepares the ground for updating the principles in the cyber era. The Declaration also lays the groundwork for a new phase of cooperation in the field of human rights protection at both the national and international levels and draws attention to the issue of protection of intellectual property rights in the context of human rights in the information society. The ideas of the Declaration of the Committee of Ministers of the Council of Europe on human rights and the rule of law in the information society were further developed in other documents of this international organization. Thus, in 2014, Recommendation CM / REC (2014) 6 of the Committee of Ministers of the Council of Europe to member states on a manual on human rights for Internet users was adopted. It identifies the possibility to "freely create, reuse and distribute Internet content with respect to the right to protection of intellectual property, including copyright" [21]. Thus, it is emphasized that the large-scale transformations associated with the introduction of information and communication technologies in practice in all spheres of life, should be controlled and directed in the interests of society and people. The Internet is influencing the traditional system of copyright regulation in terms of the transition from the regulation of fixed rights to the protection of information, but ways to regulate new telecommunications technologies remain within the use of intellectual property.

Information rights and intellectual property rights will take priority in them. An example is fundamental access to the Internet, as enshrined in UN documents, decisions of parliaments and constitutional jurisdictions of a number of countries [22]. Intellectual property in the information society ensures the development of scientific and technological progress and thus determines the development of society. The development of intellectual property relations has significant social consequences, especially in the field of human rights. Intellectual property law has a dual nature. On the one hand, it belongs to cultural rights in the modern catalog of human rights, on the other - to economic, because its objects are valued, like other products of human labor, and can be included in trade on a commercial basis.

Innovative development and introduction of new technologies have led to an increase in the commercial value of knowledge and the need for its legal protection. This has shifted the focus from the consideration of intellectual property rights in the context of cultural rights and freedoms to their analysis in the system of economic rights and freedoms [23]. However, in the context of scientific and technological 
progress, free movement of knowledge and information is equally important. in terms of its promotion of culture and technology, their accessibility to citizens. Therefore, it is necessary to analyze the place of intellectual property rights in the system of cultural human rights, which is the main approach in international human rights instruments. The right to the results of creative activity belongs to the group of cultural rights, the attitude to which is different. There is a view that cultural rights, as well as closely related economic and social rights, have no legal meaning, as not all of them can be protected in court, and also run counter to the constitutional principle of formal equality.

It is also pointed out that in the countries of the Anglo-Saxon legal system this group of rights belongs to moral values and not to purely legal (positive) rights [24]. The 1993 World Conference on Human Rights enshrined the provisions of United Nations General Assembly Resolution 32/130 of 16 December 1977, 217 which stated: (a) All human rights and fundamental freedoms are indivisible and interdependent; the exercise and dissemination of both civil and political and economic, social and cultural rights must be considered immediately and given equal attention; b) the full exercise of civil and political rights is impossible without the exercise of economic, social and cultural rights; (c) Steady progress in the realization of human rights depends on sound and effective national and international policies in the field of economic and social development. For the proper and comprehensive exercise of economic, social and cultural rights, it is important to comply with the principles and provisions of the Declaration on Social Progress and Development, adopted by the United Nations in 1969 [25].

In paragraph $b$ of Art. XIII of this document states the need to "establish a harmonious balance between scientific, technical and material progress and intellectual, spiritual, cultural and moral development of mankind". Thus, the essence of the modern concept of human rights is that it is necessary to combine civil and political rights, on the one hand, and economic, social and cultural rights, on the other. All human rights standards can be used to support the realization of economic, social and cultural rights. Cultural rights, which constitute an independent group of human rights, are seen as a state-guaranteed opportunity for everyone to freely use the full range of cultural goods, which includes conditions and services to meet creative needs, opportunities to engage in cultural values in society and the state. The group of cultural rights includes: freedom of 
creativity; the right of access to cultural values; the right to education; freedom of teaching; the right to participate in cultural life; the right to use the results of technical progress and their practical application; the right to information.

Cultural rights are of great social and political importance. They ensure the spiritual development of man and the progressive development of mankind. The importance of exercising cultural rights is emphasized by the creation of an international specialized organization for culture, UNESCO. Important international instruments guaranteeing cultural rights have been adopted under the auspices of UNESCO. Consolidation of cultural rights means the provided opportunity for human behavior in the cultural sphere and, accordingly, the duty of the state, individuals and legal entities not to violate or impede the exercise of these rights. The state undertakes to protect and support creative activity, as well as to create an effective legal system for the protection of the rights to the results of creative activity [25].

Regulation of public relations regarding the creation and use of the results of creative activity is carried out with the help of the legal institution of intellectual property. Intellectual property rights have also been directly enshrined and, consequently, protected by the state. The Declaration of the Rights of Man and of the Citizen of 1789 included the right to property, with which the right to the results of creative work was then identified, and it was declared sacred and inviolable. Thus, the human rights of the first generation did not directly reflect the idea of the natural and inalienable nature of the right to the results of intellectual labor. Another qualitative character was the second generation of human rights, which became a system of positive rights - that is, those that can't be realized without organizational, coordinating and other forms of state activity. The rights of the second generation include economic, social and cultural rights. These were, in particular, the right to participate in cultural life. They were formulated and enshrined in the Universal Declaration of Human Rights in 1948 and in the International Covenant on Economic, Social and Cultural Rights of 1966. This group of acts is called international human rights law, which enshrines the international community's generally accepted notions of minimum human rights standards in democratic society. In connection with these documents, a new institution of law emerged - the international protection of human rights and fundamental freedoms. 
Human rights have acquired a value that belongs to the entire international community and have been substantiated in international law as a legal standard to which all peoples and nations must strive. Thus, at the international level, the right to creative results has been included in the list of fundamental human rights. Support and protection of creativity, protection of the results of intellectual activity were directly related to the protection of individual freedom and human rights. The latter, in turn, were defined as a legally guaranteed measure of freedom (possibility) of the individual, which in accordance with the achieved level of evolution of mankind is able to ensure its existence. In the information society, along with intellectual property, one of the leading places is occupied by freedom of creativity, which provides protection of the results of creative activity, objectified in intellectual property [26].

\section{Freedom of creativity in the human rights system}

Art. 27 of the Universal Declaration of Human Rights and Art. 15 of the International Covenant on Economic, Social and Cultural Rights confirmed the inextricable link between the protection of intellectual property and the freedom of the individual and, consequently, freedom of creativity. It once again emphasizes the dual reality characteristic of intellectual creativity - not only cultural (spiritual), but also economic, because modernity is characterized not only by a tendency to strengthen the protection of personal intangible (moral) rights of authors and inventors, but also rapidly growing commercialization property (economic) rights. Freedom of creativity is one of the most important spiritual freedoms, which means that the state must minimize interference in creative activities, while providing legal guarantees for the protection of this freedom. Freedom of creativity is guaranteed by the fact that this type of activity is not subject to restrictions imposed on certain types of activities. Ensuring freedom of creativity, science, art does not mean state intervention in the creative process. Man cannot be forced to think or create.

The creative process is not subject to legal regulation, but legal regulation is needed to ensure the conditions under which creative activity would occur and a person would be able to freely realize and dispose of the results of creativity. As soon as the results of creativity find an objective form, the rules of law expressing public recognition of this result come into force. They establish the legal regime of the 
object and the protection of the rights and legitimate interests of its creator. The results of creative activity become the objects of legal relations only when they are embodied in an objective form that ensures their perception by other people. Only an objectively expressed result of intellectual activity can participate in economic turnover and be protected by the state [27].

Information and communication technologies change the quality of human life in all areas. They also affect the change in the object composition of intellectual property rights. Thus, information technology has contributed to the emergence of a new class of works multimedia, which are created in digital form, used on computers and to create which also always requires computer technology. An example is e-books, which are versions of books in electronic (digital) format. Such books have a number of advantages over traditional paper ones: compactness, special features (change the font, go to any section), cheaper text, accessibility, environmental friendliness, ease of use. Some modern artists, at least at the beginning of their careers, find in this an alternative to traditional book publishing, because this method does not involve the cost of publishing, and also allows you to find a much larger number of readers who do not need to buy books. In addition, such publications in digital content provide a closer relationship between the author and his readers, facilitate the possibility of personal communication. At the same time, the copyright is preserved - the software for production includes functions that prevent unauthorized copying of data from the e-book [28]. The content of cultural human rights, a significant part of which were the rights to freedom of creativity and creative results, was disclosed in other international legal instruments that supplement and specify the provisions of the Universal Declaration of Human Rights of 1948 and the International Covenant on Economic, Social and Cultural Rights of 1966.

The Universal Declaration on Cultural Diversity was adopted in 2001 at the 31st session of the General Conference of UNESCO. Article 5 of the document states that "cultural rights constitute an integral part of human rights that are universal, indivisible and interdependent". A prerequisite for the development of creative diversity is the full realization of cultural rights, as defined in Article 27 of the Universal Declaration of Human Rights and Articles 13 and 15 of the International Covenant on Economic, Social and Cultural Rights. "Accordingly", the document reads, "everyone 
should have the opportunity for self-expression, creativity and dissemination of their works in any language of their choice, and in particular in their native language". Article 8 reiterates the need to respect the rights of authors and creative workers, to ensure the diversity of creative offerings, and to define the special place of cultural objects and services. According to Article 9, a special role in stimulating creativity is played by state policy in the field of culture, which is designed to ensure the "free dissemination of ideas and works". The conditions for the implementation of state cultural policy are defined as follows [29].

Thus, in modern international human rights instruments, the right to the results of creative activity is included in the list of fundamental human rights and is defined as a legal value that must be protected by each state. At the international legal level, the Declaration on Intellectual Property for the first time formulated the concept of "the value of intellectual property rights". It includes the following provisions: intellectual property rights stimulate authors and provide users with equal access to the benefits of creative activity; intellectual property rights are part of any legal framework that aims to regulate in a fair manner the civil conduct of authors and users and thus to ensure the universal protection of the interests of all; intellectual property rights are a key and integral tool for solving the problem of development for all; effective intellectual property systems are essential elements in attracting investment in key sectors of the national economy, especially in developing countries and countries with economies in transition. It follows from this definition that intellectual property and the rights associated with it have economic, legal, cultural and ethical meanings at the same time.

The prospect of their development and strengthening is related to the tasks: to intensify efforts to ensure that authors and users in any part of the world obtain the appropriate intellectual property rights; take measures to ensure that authors and users in all countries of the world know about their intellectual property rights, and to demystify intellectual property issues; make efforts to expand public knowledge about intellectual property, intellectual property rights, to increase interest in intellectual creativity; take measures to depoliticize intellectual property issues; to stimulate the development policy of the intellectual property market in order to expand their effective use.

One of the guiding principles enshrined in the 2000 Declaration on Intellectual Property should be noted: "Intellectual property rights 
must be further developed in order to ensure an appropriate balance between the protection of copyright and the interests of users of intellectual property" [30]. In the age of the Internet and high technology, intellectual activity is becoming the main activity of more and more people and in these conditions it is necessary to form an appropriate legal awareness of the value of intellectual property rights. Current problems in the protection of intellectual property rights, the spread of intellectual piracy and counterfeiting, infringement of intellectual property rights on the Internet are associated not only with the shortcomings of the law and the shortcomings of the organizational nature.

There is a lack of due respect for intellectual property, understanding of its importance in the information society. The objects of law include "products of a spiritual and intellectual nature" and "personal intangible goods", as well as "products of spiritual creativity and intellectual property rights" and "intangible personal goods". Creative activity or simply creativity is a purposeful activity of the human brain as a result of which something qualitatively new is created, which is distinguished by originality, uniqueness and sociohistorical uniqueness. The result of creative activity, which meets the requirements of the law, is the object of intellectual property rights, which the law assigns to the creator. This result is a product embodied in an objective form, which, depending on the content, is called a literary or artistic work, invention, utility model, industrial design. Intellectual property law also extends to a number of other results related to intellectual property rights, in particular, such as knowhow, plant varieties and animal breeds, as well as trade names, trademarks, geographical indications, it means of individualization of participants in civil law turnover, as well as their products, works, services. Creativity is unique to man, whose brain can create only ideal images, not objects of the material world. Therefore, the results of creative activity, which are the objects of intellectual property law, in contrast to the objects of property law, have an ideal nature, do not undergo wear and depreciation and become obsolete only morally.

Developing the creative potential accumulated earlier, each person becomes a potentially creative person and embodies the results of complex mental processes in the results of intellectual activity. The protection of intellectual property rights is ensured by granting the creator exclusive rights of a personal non-property and property nature in relation to the object created by him. According to the purpose of 
intellectual activity is traditionally divided into spiritual creativity and scientific and technical creativity. In view of this, the results of creative activity are objects of literary and artistic property, which are protected by copyright, and objects of industrial property, which are protected by industrial property rights. Objects that are protected by patent and copyright law are characterized by the presumption of creative work, which is invested by the authors in their creation. To obtain legal protection of means of individualization, the creative nature of their origin has no legal significance.

The combination of copyright and industrial property law, the identification of their common features are caused by the needs of theory, education, development of legislation and law enforcement, which are aimed at improving the system of protection of intellectual property. To unite different types of objects of intellectual property rights allows, first of all, the intangible nature, the creative nature of the activity in their creation, as well as the exclusive nature of the rights assigned to the creators of intellectual property. The characteristics of intellectual property rights, which are based on human creativity, should take into account that the creative activity itself remains outside the scope of legal regulation. The right to the results of creative activity is closely connected with the freedom of creativity as an element of the system of human rights and freedoms. The main forms of freedom are also intellectual freedom, freedom of creative, scientific or technical activities [31].

The nature of creativity has two aspects: persocentric - creativity is the realization of the abilities of the subject of creative work, sociocentric - creativity acts as a human activity, the result of which is a socially significant product. Thus, the freedom of creativity in law is positioned in two senses: as a manifestation of individuality, uniqueness and human autonomy, as a principle of the spiritual foundations of the constitutional order - one of the vital interests of the individual, society, state. This means that with a pronounced creative attitude of the individual, his activity is aimed at selfexpression 264. However, the result of such activity can be socially significant values in the spiritual or economic spheres. Such socially significant values are the objectified results of creativity, legally enshrined in law. The concept of "freedom of creativity" is broader than the "right to freedom of creativity" [32].

Freedom of creativity, along with the state-guaranteed right to create literary, artistic and other works, conduct research, invent, 
stage activities, proclaims the general principle of spiritual and cultural relations, prevention of ideological dictate, control and censorship by the state, its non-interference in the creative process and ideological diversity. At the same time, it should be noted that freedom of creativity should not be absolute, as it can lead to abuse of rights - a situation where a person in the process of exercising his right goes beyond its content. We are talking about the contradictory and complex relationship of the principle of freedom of creativity with the norms of morality and religion, with political tendencies, which include prohibitions on the use of certain vocabulary, symbols, the commission of certain actions. No kind of creativity, to which there is public access, must contain signs of extremism, insult the honor and dignity, religious, national and other rights and freedoms of others, threaten the national security of the state.

Thus, the concept of "creative freedom" can act as a principle of spiritual and cultural life of a democratic society, and as a subjective right to creative activity. Freedom of creativity should be considered as the right of everyone independently, without the intervention of the state or other persons to create works of art, science, literature, inventions, to engage in creative activities in other areas. This freedom embodies the social value of mental work, the dignity of a scientist, a creative worker. Freedom of scientific, technical, artistic creativity implies the right of everyone to unhindered participation in scientific research, development of literature and art, inventive and innovative activities. Any creative activity is a process of creating qualitatively new material and spiritual values. By definition, V.P. Avdeeva, "creative activity is seen as a creative independent intellectual activity of man in various spheres of life, which involves the achievement (creation) of a qualitatively new result" [33]. Accordingly, freedom of creativity means a secure opportunity for everyone to creative activity in various fields.

The constitutions of many countries guarantee the right to create literary, artistic, scientific and other works, to conduct scientific research, to engage in other creative activities in accordance with their interests and abilities. Freedom of creativity as an intellectual, independent process is provided (guaranteed) by the state by establishing prohibitions on interference in these activities, enshrining certain constitutional principles and guarantees (freedom of thought and speech, prohibition of censorship, etc.) [34]. Freedom of human creativity as a state-guaranteed opportunity, according to 
O.V. Sazonnikova, includes the following elements: the choice to be creative or not; choice of type of creativity, way of participation in it, forms of organization of creative process; the right to develop creative abilities; the right to state support for creative activity; the right to dispose of the results of creative work; the right to protect the freedom of creativity and the results of creative work [35].

The first three elements of creative freedom, in fact, are not subject to legal regulation, as they cover the creative process, which is based on the inner experience of the individual and based on self-regulation. The freedom of creativity guaranteed in the constitutions means the creation of conditions for the exercise of this freedom, first of all, by the constitutional establishment of the legal protection of intellectual property, which already acts as an independent object of constitutional regulation. State support and protection of creative results is a serious stimulus for creativity. Abilities and desire to create are a special quality of man - creativity. The man-creator and the creative class of people are now the decisive force of the knowledge economy. One of the means of encouraging creativity is the protection of the results of creative work and their legal form in the form of intellectual property. This is a more important area of state cultural, educational and innovation policy [36].

Promoting the right to creative activity and legal protection of intellectual property in the conditions of innovative development and knowledge economy is one of the criteria for the effectiveness of state power. The international community recognizes that creativity is one of the driving forces of sustainable development, would promote the development of culture and progress through the widespread dissemination of creative achievements. Studies of human potential emphasize that the more people participate in creative work, the more such people, the higher the quality of society and economy. Insufficient attention to the protection of the rights of creators of intellectual products leads to material, moral and political damage [37].

Freedom of creativity is a right without the realization of which the work of a researcher, inventor, or any other creative worker is impossible. The right to intellectual property is designed to help the creative worker, realizing their abilities, investing their work, to obtain adequate to these costs income and reward. Freedom to dispose of the results of their creative work is the ability to independently determine the legal fate of the result of creative activity. It also includes the right to protect infringed creative rights, 
including the protection of intellectual property. It is this logic that has led to the emergence in modern constitutions, along with the proclaimed right to the results of creative activity, of providing special guarantees for the protection of intellectual property. The result of creative activity, as an object of relations governed by intellectual property rights, has the following properties: has an intangible nature; embodied in an objective form; transmitted by playback; has sufficient certainty for legal protection; belongs to a type of intellectual activity that has commercial value [38].

Modern constitutions guarantee citizens freedom of literary, artistic, scientific and technical creativity, protection of intellectual property, copyright, moral and material interests arising in connection with various types of intellectual activity. States recognize the right of every citizen to the results of his intellectual, creative activity, establish a direct ban on the use or dissemination of these results without the consent of the author, guarantee jurisdictional and non-jurisdictional means of protection of violated or disputed rights. The provisions of modern constitutions on the protection of intellectual property serve as a basis for the introduction of a wide range of measures to strengthen the protection of the rights of creators of intellectual property (authors, performers, inventors, etc.). Such measures are necessary when the results of creative activity become the subject of ever-increasing market circulation, because in many cases the interests of authors may conflict, on the one hand, with the needs of society interested in wider and free use of the author's creative result on the other hand, with the interests of commercial structures, to which the author in many cases transfers the rights to his work.

Guarantees for the results of creative activity introduce the fundamental principle of all modern legislation on intellectual property - the provision that the exclusive right to the result of intellectual activity created by creative work, originally arises from the author, and to other persons can pass from the author only by contract or other grounds established by law. Guarantees also define the general conceptual approach to the subject of intellectual property law, which could be defined as special intellectual legal relations, in social relations that determine the legal status of a person as a creator of creative results, as well as the rights and responsibilities of this person, relations with society and the state concerning creative results to which the law gives legal value as results of creative activity. 
Права людини в Україні та у зарубіжних країнах: традиції та новації

Intellectual property rights should not be confused with the natural inalienable human right to creativity and the use of its results. The latter is inherent in the human person as such, while intellectual property rights are, above all, a means used by states to stimulate invention and creativity for the benefit of society as a whole.

Therefore, the core of the legislation on intellectual property should be the subjective rights of the creator of this property, enshrined at the constitutional level. As a natural law, intellectual property law refers to objects that are the result of creative activity, as the latter is related to the identity of the author and serves as an expression of his individuality. Natural law means that it exists independently of the will of the state, which should not violate it. In modern conditions, the creator acquires the status of the main figure of social development. The development of intellectual activity and intellectual property will be largely determined by the attitude of the state and society to the person of the creator, which should be defined in the laws of countries.

\section{Conclusions}

Recognition of intellectual property rights is important in determining a person's legal status and requires legal certainty on a number of issues. From the point of view of human rights, the problem of the ratio of personal (individual) and collective (public) in intellectual property in the conditions of cooperation, collective forms of creativity needs theoretical development. In this case, the question of legal personality arises.

The subject of intellectual property in modern conditions is not only the creator, a representative of the intelligentsia, but also the right holder who bought the patent, providers - organizations that provide services on the Internet, certain segments of the population, social groups, the people as a whole. Of particular importance is the problem of conflict of public and subjective interests in the exercise of intellectual and legal relations of their rights.

Human rights have acquired a value that belongs to the entire international community and have been substantiated in international law as a legal standard to which all peoples and nations must strive. Thus, at the international level, the right to creative results has been included in the list of fundamental human rights. Support and protection of creativity, protection of the results of intellectual activity were directly related to the protection of individual freedom and 
human rights. The latter, in turn, were defined as a legally guaranteed measure of freedom (possibility) of the individual, which in accordance with the achieved level of evolution of mankind is able to ensure its existence. In the information society, along with intellectual property, one of the leading places is occupied by freedom of creativity, which provides protection of the results of creative activity, objectified in intellectual property

Freedom of creativity is a right without the realization of which the work of a researcher, inventor, or any other creative worker is impossible. The right to intellectual property is designed to help the creative worker, realizing their abilities, investing their work, to obtain adequate to these costs income and reward.

Modern constitutions guarantee citizens freedom of literary, artistic, scientific and technical creativity, protection of intellectual property, copyright, moral and material interests arising in connection with various types of intellectual activity.

Therefore, the core of the legislation on intellectual property should be the subjective rights of the creator of this property, enshrined at the constitutional level. As a natural law, intellectual property law refers to objects that are the result of creative activity, as the latter is related to the identity of the author and serves as an expression of his individuality. Natural law means that it exists independently of the will of the state, which should not violate it. In modern conditions, the creator acquires the status of the main figure of social development. The development of intellectual activity and intellectual property will be largely determined by the attitude of the state and society to the person of the creator, which should be defined in the laws of countries.

\section{References:}

1. Кейзеров H. Духовное имущество как комплексная проблема Общественные науки и современность. 1992. № 4. С. 17.

2. Орехов А.М. Интеллектуальная собственность: опыт социально-философского и социально-теоретического исследования. Москва, 2007. 224 с.

3. Commission of the European Communities (1996b), Living and working in the information society: People first (Green Paper COM (96) 389). Brussels: European Commission. URL: http://aei.pitt.edu/1227/ 1/live_work_info_society_gp_COM_96_389.pdf 
Права людини в Україні та у зарубіжних країнах: традиції та новації

4. IS-EEUROPE 2002 - eEurope 2002, An Information Society For All, Action Plan. URL: https://cordis.europa.eu/ programme/rcn/801_en.html.

5. Підсумкові документи Всесвітнього саміту 3 питань інформаційного суспільства. Туніське зобов'язання. URL: http://old.apitu.org.ua/wsis/tz.

6. Тоффлер Е. Нова парадигма влади / пер. з англ. Харків, $2003.688 \mathrm{c}$.

7. Кастельс М. Галактика Интернет: размышления об Интернете, бизнесе и обществе / под ред. В. Харитонова. Екатеринбург, 2004. 328 с.

8. Гегель Г.Ф.В. Философия права / пер. с нем. ; ред. и сост. Д.А. Керимов и В.С. Нерсесянц. Москва : Мысль, 1990. 524 с.

9. Gouldner A.W. The Future of Intellectuals and the Rise of the New Class: A Frame of Reference, Theses, Conjectures, Arguments and an Historical Perspective on the Role of Intellectuals and Intelligentsia in the International Class Contest of the Modern Era. New York : Seabury Press, 1979. $121 \mathrm{p}$.

10. Бурдье П. Поле интеллектуальной деятельности как особый мир / пер. с фр. Н. А. Шматко. Москва : Socio-Logos, 1994. 288 c.

11. World Intellectual Property Declaration by the Policy Advisory Commission, WIPO Pub. № 836, 2001.

12. Sartor Giovanni. Human Rights in the Information Society (November 11, 2010). URL: https://ssrn.com/abstract=1707724; http://dx.doi.org/10.2139/ssrn.1707724.

13. Декларація тисячоліття Організації Об'єднаних Націй. Документ 995_621, поточна редакція від 08.09.2000. URL: http://zakon.rada.gov.ua/laws/show/995_621.

14. Ethics and human rights in the information society. Proceedings, synthesis and recommendations Organized by the French Commission for UNESCO in cooperation with UNESCO and the Council of Europe 13-14 September 2007 Strasbourg. URL: http://www.ifapcom.ru/files/Documents/2009/ethics2009.pdf

15. IFAP. Программа ЮНЕСКО. Информация для жизни. Организация Объединенных Наций по вопросам образования, науки и культуры. URL: https://www.ifap.ru/ofdocs/unesco/ program.htm.

16. Юрченко О.А. Реалізація Програми ЮНЕСКО «Інформація для всіх» в Україні. Документознавство. Інформологія. 2014. № 3. C. 66-71. 
17. Генеральная конференция, 36-я сессия, Париж 2011 г. 36 C. 49. 10 октября 2011 г. Кодекс этики для информационного общества, предложенный Межправительственным советом программы «Информация для всех». URL: http://unesdoc.unesco.org/images/0021/002126/212696r.pdf.

18. Code of Ethics for the Information Society. The Intergovernmental Council of the Information for All Programme of UNESCO. URL: http://unesdoc.unesco.org/images/0021/ 002126/212696e.pdf.

19. Конвенція про захист прав людини і основоположних свобод. URL: http://zakon. rada.gov.ua/laws/show/995_004.

20. Declaration on Human Rights and the Rule of Law in the Information Society. CM (2005) final. Publ. N060508/h/2). URL: www.coe.int/t/dgap/goodgovernance/Activities/Public_participation internet_governa-nce/Declaration-Information

Society/011_DeclarationFinal\%20 text_en.asp.

21. Конвенція про кіберзлочинність (ETS No.185). URL: http://zakon.rada.gov. ua/ laws/show/994_575.

22. Конвенція про захист осіб у зв'язку з автоматизованою обробкою персональних даних. Страсбург, 28 січня 1981 p. URL: http://zakon.rada.gov.ua/laws/show/994_326.

23. Рекомендація CM/REC(2014) 6 Комітету міністрів Ради Європи державам-членам щодо посібника 3 прав людини для інтернет-користувачів (ухвалена Комітетом міністрів 16 квітня 2014 р. на 1197-му засіданні постійних представників міністрів). URL: https://rm.coe.int/16802e3e96.

24. Report of the Special Rapporteur on the promotion and protection of the right to freedom of opinion and expression. Frank La Rue. URL: https://www2.ohchr.org/english/bodies/hrcouncil/ 17session/A.HRC.17.27_en.pdf

25. Войниканис Е.A. Парадигмальный подход к исследованию интеллектуальных прав. Москва, 2016. С. 19-20.

26. Young K.G. Constituting Economic and Social Rights. Oxford : Oxford University Press, 2012. 384 p.

27. Alternative Approaches and Ways and Means within the United Nations System for Improving the Effective Enjoyment of Human Rights and Fundamental Freedoms: A/RES/32/130. URL: http://www.un.org/documents/ga/res/32/ares32r130.pdf.

28. Декларация социального прогресса и развития. Принята резолющией 2542 (XXIV) Генеральной Ассамблеи 1969 2. URL: http://www.un.org/ru/documents/decl_conv/ declarations/socdev.shtml. 
Права людини в Україні та у зарубіжних країнах: традиції та новації

29. Серебренников Владимир. ЮНЕСКО и права человека. URL: lib.bsu.by/bitstream/123456789/31004/1/ 1996_1_JILIR_serebrennikov_r.pdf

30. Гура М. Особливості поняття «об’єкт авторського права» та його ознаки у законодавстві зарубіжних країн (порівняльноправовий аспект). Інтелектуальна власність. 2003. № 3. С. 7-11.

31. Конюшкина Ю.А. Права человека на свободу творчества в сети. Вестник Московского финансово-юридического университета. 2013. № 4. URL: https://cyberleninka.ru/article/n/ prava-cheloveka-na-svobodu-tvorchestva-v-set.

32. Всеобщая декларация ЮНЕСКО о культурном разнообразии. Принята 2 ноября 2001 г. Генеральной конференцией Организации Объединенных Наций по вопросам образования, науки и культуры. URL: http://www.un.org /ru/documents/decl_conv/declarations/cultural_diversity.shtml.

33. World Intellectual Property Declaration by the Policy Advisory Commission. WIPO Pub. № 836, 2001.

34. Авдеева В.П. Проблемы правового обеспечения свободы творчества и охраны интеллектуальной собственности. Тюмень, 2009. C. 16.

35. Сазонникова Е.В. Содержание свободы творчества. Журнал российского права. 2009. № 5. С. 52-59.

36. Эдиев Р.А. Государственная политика в области защиты интеллектуальной собственности. Ростов-на-Дону, 2016. 23 с.

37. ВОИС. Комитет по развитию и интеллектуальной собственности (КРИС) Двадцать первая сессия. Женева, 14-18 мая 2018 г. Компиляция замечаний п предложений государств-членов с указанием вопросов, рекомендованных к рассмотрению в рамках пункта повестки дня «интеллектуальная собственность и развитие». URL: https://www.wipo.int/edocs/ mdocs/mdocs /ru/cdip_21/ cdip_21_8_rev.pdf

38. Корчагин Ю.А. Человеческий капитал - основной фактор развития инновационной экономики. URL: http://viperson.ru/articles/yuriy-korchagin-chelovecheskiy-kapitalosnovnoy-faktor-razvitiya-innovatsionnoy-ekonomiki. 